\title{
WILLIAM FREDERICK V. ATKINSON
}

$1867 \cdot 1944$

William Frederick V. Atkinson, a member of the Society since its formation and, in fact, one of the half-dozen individuals attending the meeting in Montreal whereat the Society came into being, died at his home in Toronto on May 15. He was 77 years of age.

Born at Echemin, Quebec, he was the son of the late Mr. and Mrs. Henry Atkinson. He received his education at Bishop's College, Lennox. ville, and took special study at Laval University. He entered his father's business of saw-milling and logging and later built and operated his own sawmill and timber lands at St. Paul, Quebec.

Originator of plans for the development of the Magdalen Islands, Que., Mr. Atkinson held a number of outstanding posts in forestry engineering, first in Northern Michigan, and later in Quebec, where he served as inspector of forest protection for the Provincial Government.

Chief forester for the Spanish River Pulp and Paper Mills for nine years, he also served several years as wood manager for the Dryden Paper Co., and later was connected with the pulpwood operations of the St. Regis Paper Co., Godbout, Que.

Mr. Atkinson moved to Toronto six years ago and was associated with several scientific and engineering societies including the National Geographical Society, a Fellow of the Canadian Geographical Society, Rideau Curling Club, Ottawa, the Rotary and Victoria Curling Club, Toronto.

He was at one time chief forester for the Commission of Conservation for the Dominion. He was the first to advocate and plan for forest inspection and survey by airplane. His service had included examining and reporting on power development on many rivers and a number of mining projects in Northern Ontario and Nova Scotia.

He is survived by his wife, Constance Temple Atkinson: two daughters, Mrs. W. P. S. Butterworth of Ottawa and Mrs. F. R. Oliver of Toronto; a son, Capt. F. Temple Atkinson with Royal Rifles of Quebec, a prisoner at Hong Kong; and two grandchildren.

\section{NEWS AND NOTES}

\section{NEWSPRINT INDUSTRY'S ACHIEVEMENTS}

A concise and graphic statement of the achievements of Canada's News. print Industry, in furthering the war effort, has recently been published by the Newsprint Association of Canada. Through the courtesy of that Association a copy is being mailed with this issue of The Forestry Chronicle. Members will find this outline of the accomplishments of one of Canada's great forest industries particularly interesting. 